\title{
Citizen Strangers: Identity Labelling and Discourse in the French Mandatory Syria, 1920-1932
}

\author{
Victoria Abrahamyan \\ University of Neuchâtel, Switzerland \\ viktorya.abrahamyan@unine.ch
}

\begin{abstract}
This article explores the roles played by Armenian refugees in the politics of identity in Mandatory Syria by examining how their arrival shaped the discourses of inclusion and exclusion. It does so by analysing three key events: the Armenians' access to citizenship and voting rights (1924-1925), the Great Syrian Revolt (1925-1927), and the arrival of new Armenian refugees (1929-1930) - during which a 'Syrian' identity was gradually confirmed against the Armenian newcomers. Making use of discursive narratives by Syrian and Armenian political parties, media outlets and pamphlets, the article demonstrates that the discourse against the Armenian refugees played a decisive role for both hosting and incoming communities to construct mutually excluding national identities. If the Arab nationalists used the anti-Armenian discourse as an opportunity to define a 'Syrian' national identity closely identified with Islam and Arabness, similarly, it was used by the Armenian political elite to mobilise Armenian refugees.
\end{abstract}

\section{Keywords}

Syria - refugees - state-building - discourse - identity construction - nationalism

\section{Introduction}

Throughout centuries, displacement and population resettlement have not only been an important weapon of war, but also a key instrument for statecraft in the European empires and in the Middle East alike. Both in the past and the present, forced migration has helped consolidate power by ensuring control 
over contested territories, better monitor populations, and undertake social and demographic engineering. In doing so, displacement has also contributed to the creation or the consolidation of national and ethnic identities. This was particularly true during the first decades of the twentieth century, which witnessed the interplay between large numbers of refugees on the move caused by forced displacements and the strengthening of the nation-states. Reflecting upon this interplay, Aristide Zolberg saw the formation of the nation-states as a refugee generating process, ${ }^{1}$ while Nevzat Soguk argued that refugee presence had 'disruptive' but also 'recuperative' effects in the hosting states, becoming both a problem and a resource to the statecraft. ${ }^{2}$ Peter Gatrell has similarly pointed out that while states make refugees, refugees can also make states. $^{3}$

Historians of the Middle East have picked up and developed this idea further in the past two decades by showing the central roles played by the refugees and immigrants across the Middle East. Laura Robson, for one, has shown how refugee management became a major raison d'être of the League of Nations and the British and French mandate authorities alike. ${ }^{4}$ Keith Watenpaugh has written extensively on what he calls the 'survivors' bargain' - the policies of the French mandatory authorities towards the Armenian refugees in Syria, as well as the genesis of the modern humanitarian assistance. ${ }^{5}$ Benjamin Thomas White has examined the struggle between Arab nationalists and the French colonial rulers, precipitated by the coming of Armenian and Kurdish refugees to Syria. ${ }^{6}$ Most recently, Stacy Fahrenthold has shown how French mandatory authorities made claims over the Syrian and Lebanese migrants abroad to strengthen their colonial power in the Levant. ${ }^{7}$

1 Aristide Zolberg, 'The formation of new states as a refugee-generating process', Annals of the American Academy of Political and Social Science 467 (1983) 24-38.

2 Nevzat Soguk, States and strangers: refugees and displacement of statecraft (Minneapolis 1999).

3 Peter Gatrell, The making of the modern refugee (Oxford 2013) 175.

4 Laura Robson, States of separation: transfer, partition, and the making of the modern Middle East (Berkeley 2017).

5 Keith D. Watenpaugh, Bread from stones: The Middle East and the making of modern humanitarianism (Oakland 2015); K. Watenpaugh, 'Towards a new category of colonial theory: colonial cooperation and the survivors' bargain - the case of the post-genocide Armenian community of Syria under French Mandate', in: Nadine Méouchy and Peter Sluglett (eds), The British and French Mandates in comparative perspectives (Leiden 2004) 597-622.

6 Benjamin Thomas White, 'Refugees and the definition of Syria 1920-1939', Past and Present 235:1 (2017) 141-178.

7 Stacy Fahrenthold, Between the Ottomans and the Entente: The First World War in the Syrian and Lebanese diaspora, 1908-1925 (New York 2019). 
This emerging body of literature often interacted with the critical readings on humanitarian assistance provided to the Armenian refugees in the aftermath of the Armenian Genocide. Adapting the orientalist critique of Edward Said, Joanne Laycock, for instance, has shown how orientalist discourse informed not only the image of the Armenian refugee, but also the nature and the practice of the humanitarian relief. ${ }^{8}$ Davide Rodogno, on the other hand, has shown the genesis and transformation of one of the biggest international humanitarian organisations - Near East Relief (NER), formed in 1915 to assist the Genocide survivors. ${ }^{9}$ In addition, Jaffa Panken has explored the media use and strategies of the NER to generate public interest and raise funds. ${ }^{10}$

Despite the considerable advances of the literature, the direct and indirect roles played by the refugees themselves in the shaping of modern Syria has remained understudied, particularly due to the lack of scholarly engagement with refugee language sources. In addressing this lacuna, this article draws on the previous research and seeks to explore the roles played by the Armenian refugees in constructing insiders and outsiders in the French mandatory Syria. It does so by analysing three key events - the access to citizenship and voting rights for the Armenian refugees (1924-1925), the Great Syrian Revolt (19251927), and the arrival of new Armenian refugees (1929-1930). Although other groups of refugees - Kurds and Assyrians - were also resettled in Syria along with the Armenians in the interwar years, this article will discuss only the case of Armenians, who were the largest refugee community in this country - leaving a major imprint on the Syrian national fabric.

The article argues that the interplay between the Arab nationalist discourse against the Armenian refugees and the discourses adopted by the refugee political elites, helped construct the 'otherness' of both communities and played a vital role in developing mutually excluding national identities. In addition, a distinct Armenian identity in Syria was further forged as a result of external factors, namely the continuous support provided by the French mandatory authorities and the League of Nations in exchange for a purportedly political loyalty and as a way of legitimising their 'mission' in mandatory Syria. I explore this process by utilising a series of primary sources. Newspapers, in particular, are of the upmost importance for this study, since the interwar period saw an unprecedented flourishing of press in Syria, providing an important platform

8 Joanne Laycock, Imagining Armenia: Orientalism, ambiguity and intervention 1878-1925 (Manchester 2009).

9 Davide Rodogno, 'Beyond relief: a sketch of the Near East Relief's humanitarian operations, 1918-1929', Monde(s) 2:6 (2014) 45-64.

10 Jaffa Panken, "Lest they perish": The Armenian Genocide and the making of modern humanitarian media in the U.S., 1915-1925 (Thesis The University of Pennsylvania, Pennsylvania 2014). 
where leading intellectuals from both communities expressed their views and engaged in discussions. ${ }^{11}$

For the purposes of this study two prominent Arabic language newspapers are consulted - Al-Qabas (1928-1958) and Al-Sha'b (1927-1937). ${ }^{12}$ Both newspapers were dailies published in Damascus and were famous for their nationalist attitude, therefore many anti-Armenian articles appeared in the pages of these two newspapers. The reactions of the Armenian refugees to this burgeoning anti-Armenian rhetoric were expressed in the community's own press outlets. A series of Armenian language newspapers have therefore also been analysed to capture the latter. These include newspapers from Aleppo, such as Suriayakan Mamul and Yeprat, but also Lebanon (Beirut), Arev (Alexandria) and Husaber (Cairo). In selecting these outlets over others, an effort has been made to maintain a balance between the different political party organs and independent newspapers. ${ }^{13}$ In addition, French diplomatic records, the archives of the League of Nations' Permanent Mandates Commission as well as those of the Armenian Catholicos of Cilicia are consulted.

The article consists of four parts. The first explores the link between displacement, nationalism and national identity. Parts two and three are devoted specifically to the internal and external factors - the Syrian nationalist discourse and the policies of the French mandatory authorities and the League of Nations vis-a-vis the Armenian refugees. Finally, the last section is concerned with the discourses and strategies put forward by the refugee political elites.

\section{Displacement, Nationalism and National Identity}

The exodus and genocide of the Anatolian Armenians which unfolded between 1914 and 1922 constitutes one of the most important instances of mass

11 There were 490 press titles in Syria and Lebanon during the interwar period: 263 in Beirut, 92 in Damascus, 31 in Aleppo and 22 in Tripoli; see Nadine Méouchy, 'La presse de Syrie et du Liban entre les deux guerres 1918-1939', Revue des Mondes Musulmans et de la Méditerranée 95-98 (April 2002) 55-70. By the end of the Mandate (1946) the Armenian community had thirty publications in Syria; see Nicola Migliorino, (Re)constructing Armenia in Lebanon and Syria: Ethno-cultural diversity and the state in the aftermath of a refugee crises (New York 2008) 69.

12 Both newspapers were consulted at the library of the American University of Beirut.

13 Suriayakan Mamul (1922-1927) was the organ of the Hunchak party; Yeprat (1927-1949) was the organ of the Ramkavar party; Lebanon (1924-1935) was an independent periodic; Arev (1915-1944) was the organ of the Ramkavar; Husaber (1926-1936) was an ARF organ. All the Armenian newspapers were consulted at the national library of Armenia in Yerevan and the library of Mekhitarist congregation in Vienna. 
displacement and dispossession in the Ottoman lands. ${ }^{14}$ According to different estimates, between 1.2 and 1.5 million Armenians ${ }^{15}$ were forcibly removed from their homes and sent on death marches towards Deir ez-Zor and Mosul during the First World War. Around 1 million Armenians perished. The caravans of survivors arrived in Syria, turning Aleppo into a major hub for the Armenian refugees. Mandatory authorities estimated that approximately 200,000 Armenians had passed through the city, 75,000 of whom had resettled in the Aleppo province alone. ${ }^{16}$ The Ottoman Empire's politics of expulsion and resettlement made forced migration the characteristic mark of nationalism across the Middle East. ${ }^{17}$

Nationalism, a new ideology popular since the end of the nineteenth century, was understood to be upholding the principle whereby ethnic boundaries should not cut across political ones. Accepting the dominance of a certain ethnic group and its ideologies in a given state, nationalism as a source of political legitimacy became a key characteristic of the 'nation-states' in the twentieth century. ${ }^{18}$ This new conception was fundamentally different from the previous practices of the Ottoman empire where belonging was defined not by birthplace - i.e. territory alone, but rather by the inclusion in a certain social community - a millet ${ }^{19}$ based on religious, linguistic and cultural characteristics.

In Syria, nationalism was primarily marked by the struggle for independence from France which had received Syria's mandate in 1920 under the supervision of the League of Nations. The mandatory framework served as a well-designed cover for the French colonial ambitions, packaged as the protector of the 'chrétiens d'Orient' and the 'mission civilisatrice'. While the

14 On the Armenian Genocide see: Richard G. Hovannisian, The Armenian Genocide in perspective (New Brunswick 1986); Vahakn N. Dadrian, The history of the Armenian Genocide: Ethnic conflict from the Balkans to Anatolia to the Caucasus (Providence 1995).

15 There is no unanimity among academics regarding the number of Armenian victims of the Genocide. The figures suggested range from 1.5 million by Bernard Lewis (1968) to between 460,000 and 860,00o by Toynbee (1916), to 1 million by Lepsius (1918), see: Migliorino, (Re)constructing Armenia in Lebanon and Syria, 30.

16 Centre des archives diplomatiques de Nantes, series Mandat Syrie-Liban (hereafter CADN-SL), no. 575, Installation de réfugiés arméniens à Alep, Beirut, 8 July 1940.

17 Dawn Chatty, Displacement and dispossession in the modern Middle East (Cambridge 2010) 289 .

18 Ernest Gellner, Nations and nationalism (Oxford 1983) first edition.

19 The millet system allowed the Ottoman rulers to efficiently organise the empire's population into communities by devolving power to trusted intermediaries and community leaders. There were three basic millets: the Greek, the Jewish and the Armenian; see in Karen Barkey and George Gavrilis, 'The Ottoman millet system: non-territorial autonomy and its contemporary legacy', Ethnopolitics 15:1 (2016) 24-42. 
civilisation project was partially acceptable to the westernised Syrian elite, the political agenda it contained was not. ${ }^{20}$

Home to various religious and ethnic communities, Syria had emerged as a creation of the Great Powers. As these communities showed a high degree of unity against the colonial rule, the French exploited ethnic and religious groups as a counterweight against the majority Sunni Arabs implementing a divide-and-rule strategy. ${ }^{21}$ In this context of uncertainty and political tension, the mere presence of the incoming Armenian refugees came to be regarded as undesirable and Arab nationalists perceived them as an obstacle to the construction of the Syrian nation. As a result, these refugees were soon caught in a political and social 'no man's land' where the Syrian hosts increasingly viewed their presence as a sectarian, political and economic threat. ${ }^{22}$

In turn, the vulnerable status of a refugee, the terrible collective experience together with the constant sense of insecurity pushed the Armenian refugees to mobilise political and cultural resources, as well as to accept all kinds of available support to quickly form a community. Some scholars, including Migliorino, have argued that the 'ultimate mission' of the Armenian refugees was to maintain a distinct communal cultural identity. ${ }^{23}$ It can be debated, however, whether there was a clear strategy at first among the refugees. In fact, the success in maintaining a discrete Armenian identity and forming a strong non-assimilatory community was not due to the community efforts alone, but was a result of the coming together of much stronger factors - namely, the aggressive Arab nationalist discourse against Armenian refugees, coupled with the continuous support of the League of Nations and the French mandatory authorities.

Syrian Nationalists Imagine the Nation: the 'Insiders' and the 'Outsiders'

Thousands of Armenians arrived in Syria as stateless refugees, ${ }^{24}$ which as a status was not legally defined at the time of their arrival. It was only later, in May

20 Philip S. Khoury, Syria and the French Mandate: the politics of Arab nationalism, 1920-1945 (Princeton 1987); James Gelvin, Divided loyalties: Nationalism and mass politics in Syria at the close of empire (Berkley 1998).

21 Khoury, Syria and the French Mandate.

22 Watenpaugh, 'Towards a new category of colonial theory', 601.

23 N. Migliorino, "Kulna Suriyyin"? The Armenian community and the state in contemporary Syria', Revue des Mondes Musulmans et de la Méditerranée, 115-116 (2007) 97-116.

24 A small Armenian community of about 13,000 Armenians lived mostly in Aleppo before the arrival of the refugees. They were mostly Arabic speaking and well-integrated into the Syrian society; see Suriakan taretsuyts (Aleppo 1923) 235-238. 
1926, that the League of Nations would define who constituted a 'refugee' thereby laying the foundations for the international refugee regime. This new legal status was, however, limited and selective in character for it initially applied to just two refugee groups - the Russians and the Armenians. ${ }^{25}$

Mandatory Syria - the new home of the Armenian refugees - saw a high degree of political mobilisation during the entire interwar period. In this period most of its modern-style political parties were formed - the People's Party (Hizb al-sha'b), ${ }^{26}$ the National Bloc (al-kutla al-wataniyya), ${ }^{27}$ the Communist Party, the Syrian National Social Party and the Muslim Brotherhood. The role of newspapers quickly gained importance for disseminating party ideologies and informing the public opinion. Newspapers became a political space where negotiations and confrontations took place between the competing local elites. Even though nationalistic discourse prevailed, nonetheless, different political circles held different, often conflicting views on the most debated issues of the time such as the Jewish immigration to Palestine, Syria's independence and unity, ${ }^{28}$ or economic and social problems. ${ }^{29}$ Refugee issues, seen from the Syrian nationalistic perspective, were closely related to all of those topics in one way or another and were soon taken up by the most pro-nationalist press outlets. It included the Damascene Alif B $\hat{a}^{\prime}$ (pan-Arab), al-Sha'b (nationalist), alFatâ al-'Arab (pan-Islamist), al-Qabas (National Bloc) as well as the Aleppine al-Nahda (nationalist) and many others. ${ }^{30}$ Unsurprisingly, while nationalist outlets expressed anti-refugee rhetoric, a handful of Aleppine newspapers mostly neutral or pro-mandate (al-Takaddum, Le courrier de Syrie, Doğru Yol) were famous for their pro-refugee positions.

Clearly, the 'refugee' label itself, far from clarifying an identity, implied a complex set of values and judgments. ${ }^{31}$ Roger Zetter noted in his seminal research that 'labelling is a process of stereotyping and forming clear-cut

25 League of Nations, Arrangement relating to the legal status of Russian and Armenian refugees, 30 June 1928, League of Nations Treaty Series, vol. 89, no. 2005, htpps://www.refworld .org/docid/3dd8cde56.html (accessed 30 May 2019).

26 Led by doctor 'Abd al-Rahman Shahbandar it played an important role during the Syrian Great Revolt.

27 Different nationalist circles came together forming the National Bloc in 1928 as an independence movement rather than a political party. It dominated Syrian politics until independence in 1946.

28 For example, there were three different perceptions for the unity alone - it could be Syrian, Arab and Islamic.

29 Nadine Méouchy, 'La presse de Syrie et du Liban', 58.

30 Categorisations according to the French intelligence report; see in CADN-SL, no. 906, Liste des journaux et periodiques, Damas, le 6 fevrier 1929 .

31 Roger Zetter, 'Refugees, repatriation and root causes', Journal of Refugee Studies 1:2 (January 1988) 99-106, 99-100. 
categories, a powerful process, with far-reaching consequences for those being labelled'. ${ }^{32}$ Indeed, labels are known to have power since they are charged with emotion, imply certain meanings, highlight differences and at the same time influence the public opinion. This can explain why articles about the Armenian refugees regularly appeared on the front pages of the prominent nationalist newspapers of Syria and Lebanon throughout the 1920s and 1930s: 'Our guests, Armenians',33 'Hey, Armenians, Your Danger is Great!', 34 'Smart Elements?! The Owners of the 'Real' Interests in the Country', ${ }^{35}$ 'When does the Weak Play the Game of the Strong?,', 36 to mention a few examples. Ultimately, 'The Armenians', 'Our guests, Armenians', 'The Armenian Refugees'- used either as titles or in the main body - became frequent idioms, employed to highlight the Armenian 'otherness.' ${ }^{37}$

Anti-Armenian sentiments started to emerge among the Syrian hosts once the presence of the refugees was felt more acutely, especially in the Aleppo province. Ironically, refugees insisted on staying in larger groups and opposed any attempts to be dispersed out of fear and insecurity, which further highlighted both their presence and their status as newcomers. In addition, the fact that they were non-Muslim and non-Arabic speaking further underscored their otherness in the eyes of the Syrian hosts.

Such discourse, however, cannot fully be understood without analysing the evolving historical context in which it was embedded. The close analysis of the anti-Armenian discourse conveyed by the Syrian political parties, media outlets and pamphlets allows us to propose three key moments between 1920 and 1932 that played a significant role in (re)confirming the identity of the 'Syrians' as insiders by presenting the Armenians as 'outsiders'.

\subsection{Armenian Refugees as Syrian Citizens}

The Armenian refugees' access to the Syrian citizenship and political participation was undoubtedly the first such moment. Anti-Armenian discourse took another form, especially after the signature of the Treaty of Lausanne (1923)

32 Roger Zetter, 'Labelling refugees: forming and transforming a bureaucratic identity', Journal of Refugee Studies 4:1 (1991) 39-62, 44.

33 'Duyüfinä al-ärman', Al-Ahwal, quoted in Lebanon 23 July 1926. All translations by the author.

34 'Khațrakum 'aẓïm äayuhä al-ärman', Al-Sha'b 1 September 1930.

35 Najïb al-Rïs, 'Anäșir rashïda?! Wa äșhäb mașälih̆ ‘h̆aqïqiyya' fi al-biläd', Al-Qabas 27 January 1932.

36 'Matay käna al-ḍa'ïf yala'bu lu'aba al-qawiy?', Al-Qabas 20 March 1933.

37 Notably, those titles and the Syrian attitude, in general, remained the same up until the mid-1930s, many years after the Armenian refugees were granted Syrian citizenship (1924) and were neither 'guests' nor 'refugees' in legal terms. In contrast to what the category of 'refugee' means - finding a new permanent home, 'guest' signifies temporality. 
when it became clear that the Armenian refugees could not return to their homeland and their status was to be legalised in the countries in which they resided. ${ }^{38}$ In August 1924, after just a year, French mandatory authorities granted the refugees Syrian citizenship, which subsequently triggered anti-Armenian reactions. In that sense, al-Fatâ al-'Arab newspaper warned: 'Every Syrian should know that the presence of the Armenians is a threatening danger and should it be tolerated further Syria and Lebanon will be soon called 'Armenia.' ${ }^{39}$

When French mandatory authorities extended further political privileges to Armenians by granting them voting rights in 1925, the prospects of Armenian political participation prompted heated debate among the Syrian political elite and in the press alike. Two issues, in particular, were of great importance: who was to be considered a 'Syrian', and who was entitled to make such decisions. Armenian refugees, just like their Syrian hosts, were former Ottoman citizens, but the role of religion (Islam) and ethnicity (Arabness) was now emphasised by the Syrian nationalists. Moreover, the fact that a third power - the French authorities, allowed refugees to settle, and shortly thereafter granted them citizenship and voting rights without even formally consulting the nominative Syrian government worsened the situation and created a sovereignty crisis among the Syrian nationalists: ${ }^{40}$ 'Are they the guests of the mandatory authorities or ours? [...] France opened the doors of our country wide and they came in their thousands, filled our valleys and villages and started to disturb us in our own homes. ${ }^{41}$

Syrian nationalists argued that they were the owners of the country and that it was for them to decide on such matters, not the French: 'We wish to complain against the decision of the resettlement of 100,000 Armenians in Syria, as we, the Syrians are the owners of this country and we have the right to have a say on this kind of decision $[\ldots]]^{\prime 2}$ (Emphasis mine)

38 The signature of the Lausanne Treaty in July 1923 denied the survivors of the Genocide the right to return to their homeland, ultimately making the Armenian refugees of the Southeastern Europe and the Middle East stateless; see in Watenpaugh, Bread from stones, 168.

39 Quoted in 'Hayere Suriayi ev Libanani mej' (Armenians in Syria and Lebanon), Arev 6 March 1925 .

40 Benjamin Thomas White, 'Refugees and the definition of Syria', 144.

41 Quoted in Muhattis, 'Khentin meke qar me glorer e jerhore. Hazar kheloq ashkhater en chen kercer hanel' (Khoske mejernis)' (A fool threw a stone in the hole, one thousand wise men could not bring it back (between us)), Lebanon 23 July 1926.

42 'Ïskän al-ärman fi süriyä' (The resettlement of Armenians in Syria), Al-Sha'b 21 June 1928. The article referred to the rumours that French intended to resettle more Armenian refugees in Syria. 
Subsequently, Armenian refugees' right to vote had an impact on the upcoming elections. The legislative elections of Aleppo (1926) were boycotted by the local nationalist leaders, while Armenians and other Christian communities participated. The results were just as the French expected. As an article in Al-Sha'b put it:

As for the Armenian immigrants, their number along with the number of other Christians does not allow them to have more than one representative in the parliament, nevertheless, they got two [...]. We think Armenians do not have the right to have even one representative since 80 per cent of them has left the country while staying registered. ${ }^{43}$

The newspaper article also complained of the scandalous outcome of the elections, where 'the minorities were entitled to six deputies while the [Arab] majority only five!'44 Furthermore, the decision of the French authorities to allow the Armenian refugees to vote in the country-wide constitutional assembly elections of 1928 renewed anti-Armenian reactions once again. Syrian newspapers heavily criticised the Armenians' right to participate in the elections, which were perceived as 'national', framing them a new element that had not lived in Syria for long enough to deserve the right to vote.

The Armenians did not remain silent in the face of such accusations. They, too, had started to publish newspapers immediately after their arrival in Syria. ${ }^{45}$ Moreover, the political parties - Hunchakian, ARF and Ramkavar ${ }^{46}$ that were traditionally active among the Ottoman Armenians, now had their followers in the refugee camps of Syria and Lebanon. They even had their own newspapers in which they debated the Arab nationalist accusations and expressed their positions.

If Syrian nationalists employed labels and insisted that the Armenian refugees were outsiders, thus denying a common cultural background, Armenian refugees, on the contrary, often referred to their shared Ottoman past and experiences. The Ramkavars, for example, as a response to the accusations of al-Nahda announced that the Armenians of Aleppo had as much right to

43 'Ḧuqüq al-äkthariyah wa al-äqaliyät' (The Rights of the Majority and the Minorities) $A l$ Sha'b 1 April 1928.

44 Ibid.

45 The first newspapers Hay Dzayn and Daragir appeared in Aleppo in 1918.

46 The Social Democrat Hunchakian party (also known as Hunchak) was founded in 1887 in Geneva, Switzerland; the Armenian Revolutionary Federation (ARF, also known as Dashnaktsutyun) was founded in 1890 in Tiflis, Georgia; the Armenian Democratic Liberal party (also known as Ramkavar) was founded in 1907 in Istanbul, Turkey. 
consider themselves 'Syrians' as the editors, since go per cent of Armenian refugees came from Aintab, Kilis and Marash which were all part of the Aleppo Vilaye ${ }^{47}$ during the Ottoman times. ${ }^{48}$

Yet, the Armenians were torn by this question. On the one hand, the Treaty of Lausanne obliged them to look for permanent settlement; on the other hand, by obtaining Syrian citizenship and voting rights, they were obliged by law to fulfil their citizen duties: 'This is the situation that, unfortunately, is directed at Armenians who are blamed unfairly'49

\subsection{The Syrian Great Revolt}

The Syrian Great Revolt (1925-1927) against French rule was the second key contentious episode that provoked anti-Armenian reactions in the Arab press. ${ }^{50}$ Although Armenian communists had an active role in the revolt and managed to mobilise many to fight against the French along with the Arabs, most Armenians took a neutral position. ${ }^{51}$ Thus, the head of the Armenian orthodox church announced in Damascus that 'Armenians are new-comers, loyal to the French authorities and friends with the locals [...]' and refused to take weapons that the French authorities had distributed to the Christians in the streets of Damascus in August $1925 .{ }^{52}$ This notwithstanding, the community as a whole was rather identified as siding with the French. Crucially, the fact that a few dozen Armenians had joined the French army during the suppression of the revolt provoked the most significant anti-Armenian pogroms of modern Syria. ${ }^{53}$ According to some estimates, the anti-Armenian attacks claimed 50 victims in the Damascus refugee camp in 1925 . The origins of the false news

47 Villayet was an administrative unit in the Ottoman Empire that corresponded to the modern governorate.

48 'Al-Nahdayi gergerich hodvatse; Mer hay eghbayrnerin' (The angry article of al-Nahda; To our Armenian brothers), Yeprat 23 April 1928.

49 'Hay B Kargi entroghneru' (To the Armenian B Class Voters), Yeprat 18 April 1928.

5o The Great Syrian Revolt was the largest anti-colonial insurgency in the interwar Arab East. Although the revolt failed to liberate Syria from the French rule, it provided a model for popular nationalism and resistance; see in Michael Provence, The great Syrian revolt and the rise of Arab nationalism (Austin 2005).

$5^{1} \quad$ H. Topuzyan, Siriayi ev Libanani haykakan gaghtojakhneripatmutyun 1841-1946 (History of the Armenian communities in Syria and Lebanon 1841-1946) (Yerevan 1986) 223.

52 Ibid, 225.

53 Although Armenians were slightly over-represented in the police force in terms of their percentage of the total Syrian population, nevertheless they numbered only 369 persons in 1925. The largest component of this force was composed of Arab sunni Muslims with 2,468 persons in 1925; see N. E. Bou-Nacklie, 'Les Troupes Spéciales: religious and ethnic recruitment, 1916-1946', International Journal of Middle East Studies 25:4 (November 1993) $645^{-660,653 .}$ 
about the key role of Armenians in the repression of the revolt are still an issue of contention. Several Armenian historical accounts mention anti-Armenian propaganda run mainly by the Turkish press as the main source for the rising tensions. ${ }^{54}$ The Catholicos Sahak II of the Great House of Cilicia reported shortly after the incident: 'There were rumours about Armenian troops who were looting and massacring the locals'.55 For his part, Armenian historian Hovhannes Topuzyan argued that French authorities encouraged the spread of such rumours in order to legitimise their role as a 'protector of Christians' and as a mediator between the Christians and the Muslims. ${ }^{56}$ Finally, the Armenian involvement in the revolt could divert the attention of Syrian nationalists by giving an inter-sectarian character to the conflict and thus justifying the bombardment of Damascus. ${ }^{57}$

Moreover, Topuzyan claimed that the French authorities had a clear strategy to resettle Armenian refugees in a certain way that would allow them to create Christian-Muslim or Armenian-Arab clashes whenever deemed needed. He quoted a letter that summarised the outcome of a meeting between the French High Commissioner Maurice Sarrail and the Dashnak representatives: 'The High Commissioner thinks that Armenians should be mainly resettled around Damascus and Beirut [...], refrain from the army service and instead serve in the police units. 58

The formation of police units was foreseen by the second article of the Mandate with the purpose of the protection and the preservation of the public order. The enrolment of large number of Armenians in these units, indeed, created suspicion and tensions between the hosting and incoming communities. ${ }^{59}$ Unsurprisingly, Syrian nationalists complained that France had violated the second article of the mandate. Petitions were sent to the League of Nations

54 Particularly successive anti-Armenian articles published by Cumhuriyet and Milliyet newspapers that continued throughout the 1930s, this time targeting the Armenian settlements in Northern Syria, see in CADN-SL, no. 575, Information N: 2977, Sûreté Damascus, signed by l'Inspecteur general des polices (11 December 1929); Byuzand Yeghiayan, Zhamanakakits patmutyun katoghikosutean Hayots Kilikio 1914-1972 (The contemporary history of the Armenian Catholicos of Cilicia, 1914-1972) (Antilias 1975) 264-269; H. Topuzyan, Siriayi ev Libanani haykakan gaghtojakhneri patmutyun, 227.

55 Yeghiayan, Zhamanakakits patmutyun, 265-266.

56 Topuzyan, Siriayi ev Libanani haykakan gaghtojakhneri patmutyun, 222-232.

57 Damascus was under heavy fire from French airplanes and tanks between 18 and 21 October 1925. Entire neighbourhoods were destroyed and hundreds of its inhabitants were killed. The event marked the first large-scale urban bombardment in colonial history.

$5^{8}$ Quoted in H. Topuzyan, Hayeri masnakcutyune Siriayi ev Libanani azgayin-azatagrakan sharjumnerin (The participation of the Armenians in the national liberation movements in Syria and Lebanon) (Yerevan 1968) 25 .

Ibid. 
claiming that French authorities had no right to include Armenians in the police units, for they were not 'locals' but 'hosted refugees', hence 'outsiders'. ${ }^{60}$

Even al-Takaddum, an Aleppine newspaper famous for its pro-Armenian stance, printed a series of articles that placed the blame on the Armenian refugees, noting that ' $[. .$.$] They forgot that they are guests in this country and$ were accepted here when all the doors were shut for them [...] ${ }^{61}$

Armenian refugees, in general, lamented that anti-Armenian rhetoric was the result of false news, propaganda and over-generalisation, for 'claiming the actions of a few hungry, uneducated youngsters for the entire community is not fair'.62 Moreover, 'Why then when a Cherkess or a Kurd does something wrong, it is never generalised to apply to the entire community, but it is always the case for the Armenians?' 63

\subsection{The Arrival of New Armenian Refugees}

The third key development that prompted a new peak in the anti-Armenian discourse was the arrival of about 8,000-10,000 new Armenian refugees in Syria between 1929 and $1930 .{ }^{64}$ The latter were mostly settled in northern Syria, in a region known as the Upper Jazira where the French mandatory authorities sought to resettle them in a bid to tap into their cheap manpower on 'empty and far away' lands. Ironically, it had the opposite effect, attracting more attention among the Arab nationalists instead. The latter soon started to draw parallels between the Armenian and the Jewish immigration in Palestine and raised concerns over the danger of an independent Armenian national home in the Upper Jazira.

60 Topuzyan, Siriayi ev Libanani haykakan gaghtojakhneri patmutyun, 227-228.

61 Quoted in 'Hamaynavarutyune Halepi mej' (The communism in Aleppo), Yeprat 3 September 1930.

62 'Sirian ev nor hay gaghtakannere. nor voghbergutyun' (Syria and the new Armenian refugees: a new disaster), Lebanon 26 March 1926.

63 'Suriahayutian katsutyune; pataskhanatvutyunner chiratsnek!' (The conditions of the Armenians in Syria; do not take up responsibilities), Lebanon 13 April 1926.

64 High bureaucratic pressure, extraordinarily high taxation, confiscation of properties and other pressures were reportedly the main reasons for their exodus. Their passports were stamped 'Not to re-enter Turkey', Vahe Tachjian, La France en Cilicie et en HauteMésopotamie (Paris 2004) 277-285; CADN-SL, Cabinet politique 1926-1941, no. 576, L'Arménie et les Arméniens, 32. 
In the meantime, Jews are aiming to create a national home - Israel, even though they are not numerous, they advance well in their project in Palestine. Now the Armenians that came in large numbers and 'attacked' the whole country $[\ldots]^{65}$

The mandatory powers also became the targets of such comparisons: 'French mandatory authorities aim to separate Syria from Turkey and Iraq, like the British who aimed to separate Palestine from other Arab countries by creating the Jewish national home. The French would like to achieve the same for Syria' ${ }^{66}$ The same article concluded that the French chose the hard-working and robust [Syrian] population' on purpose in order to undermine the local population within a short period of time. Once again, Armenian refugees were labelled as 'foreign elements' and 'guests':

It seems that Armenians do not understand that they are guests in this country that accepted them and they must adopt a neutral position in domestic politics [...]. As if their presence and their social and economic damage were not enough, now they aim at creating a national home $[\ldots] .{ }^{67}$ (Emphasis mine).

The organ of the National Bloc Al-Qabas was even more explicit about the status of Armenians in Syria. It warned that all the attempts to resettle Armenians and other foreign elements in Syria were in vain since they would always remain foreigners and would not deserve any sympathy [from Syrians].68 (Emphasis mine)

By categorising the Armenian refugees as 'outsiders', Syrian nationalists essentially attempted to define who was a 'Syrian' and who was not. Thus, gradually an identity boundary separating the insiders - the Syrian hosts - from the outsiders - the incoming Armenian refugees - came into existence. Syrian nationalist polemics, however, were not the only force that helped to deepen the increasing gap between 'insiders' and 'outsiders' in the mandatory Syria, since external factors played central roles as well.

65 'Al-ärman fi h̆alab' (Armenians in Aleppo), Al-Sha'b 10 July 1927.

66 'Armenians in Syria', Al-Mokattam, in CADN-SL, no. 575, Extraits des presse, Journaux du 25 decembre 1929 au 2 Janvier 1930.

67 'Khațrakum 'aẓïm äyuhä al-ärman!', Al Sha'b 1 September 1930.

68 Quoted in 'Ankeghts khosqer Al-Qabasin' (Honest Words to Al-Qabas), Yeprat 14 May 1930. 

and the French Mandate

Since their arrival in Syria, Armenian refugees were also subjected to institutionalised labels from the humanitarian perspective, which implied a welldefined client group with specific prescribed needs - food, shelter and protection. ${ }^{69}$ Special efforts to assist them were made by diverse international actors such as the French mandatory authorities, the League of Nations and other relief organisations. These efforts, essentially, sought to avoid assimilation and preserve the distinct Armenian cultural characteristics, including the religious institutions and the Armenian language 'as a residue to their collective suffering and survival experience'. ${ }^{70}$

The League of Nations, in particular, led a 'particular humanitarianism' on behalf of Armenian refugees, seeking to achieve their communal survival by promoting a collective and individual welfare that would 'prevent further erosion of the "Armenian nation" [...] through dispersal and cultural assimilation'. ${ }^{71}$ In that regard, the treatment and resettlement of the Armenian refugees soon gained importance in the relations of the French mandatory authorities and the League of Nations, the latter funding and closely monitoring the resettlement process. Among other actions, this was accomplished by the establishment of agricultural colonies along the Syrian-Turkish border and by building separate Armenian neighbourhoods in Aleppo and Beirut.

Needless to say, these efforts were in line with the French colonial policies in the Levant where the latter strived to empower non-Muslim and non-Arab communities to counter-balance the rising Arab nationalism. As one French official put it, 'we need to reinforce the Christian element on which we would need to stand to counterbalance the Muslim elements and make Syria a country of mixed population' ${ }^{72}$ Moreover, the resettlement soon became a justification for the mandate itself and a landmark for the French humanitarian prestige. The resettlement policy intended to purchase land, construct houses, and even whole neighbourhoods and villages, while providing employment to Armenian refugees. The French High Commissioner Henri Ponsot explained that:

69 Zetter, 'Labelling refugees', 44.

70 Watenpaugh, Bread from stones, 154.

71 Ibid, $160 ; 166-167$.

72 CADN-SL, n. 586, letter (n: 612 / KD) from Weygard to the ministry of foreign affairs $(25$ August 1924). 
It is necessary to help the refugees to settle permanently. This is the goal. With the Armenians what one fears is that they wish to go elsewhere as soon as they have some savings. This must be avoided, and to avoid it we must make out of them small property owners, of land, a house or a field $[\ldots] \cdot{ }^{73}$ (Emphasis mine)

Such settlement policies, coupled with the efforts to grant citizenship and voting rights, would serve the French authorities to alter the demographic picture of Syria and use the Armenians to strengthen the French colonial rule. ${ }^{74}$ Therefore, France vehemently opposed any calls to transfer these refugees out of Syria. The Treaty of Lausanne (1923), for example, foresaw a possibility 'for those who had a different ethnicity to take citizenship of the country with whom they shared the same ethnicity'. ${ }^{75}$ In the case of Armenians, this could have been Soviet Armenia. France, however, opposed any such attempts by the League of Nations, claiming that Armenians living in Syria were already selfsufficient and well settled. ${ }^{76}$

After all, a distinct Armenian community could serve the French in another way, particularly by advancing the French political agendas during the elections. Indeed, Armenian refugees overwhelmingly voted against the Syrian nationalists during the elections of 1926 and 1928. In order to realise their plans, the French authorities largely relied on one of the Armenian political parties the ARF, which was famous for its pro-western stance. As we shall see in the next section, the other two political parties, Hunchak and Ramkavar had developed more cautious politics towards the French and the Syrians alike.

It is of little surprise, therefore, that the local Arab population developed growing antipathy towards the Armenian refugees who enjoyed external support and threatened, as Syrian nationalists believed, the territorial integrity of Syria. The pattern laid down since Ottoman times where the Middle Eastern Christians, often being privileged targets for the western humanitarian interventions, were perceived allies with the foreign powers. ${ }^{77}$ Similar perceptions

73 CADN-SL, n. 575, Procès-verbal, Comité de secours aux réfugiés arméniens (24 June 1931).

74 Watenpaugh, Bread from stones, 176; Keith D. Watenpaugh, Being modern in the Middle East, revolution, nationalism, colonialism, and the Arab Middle Class (Princeton 2014) 211-308.

75 Article 32 of Lausanne Treaty, in N. Migliorino, (Re) constructing Armenia, 54.

76 Narine Margaryan, Hayots tseghaspanutyan hetevanqov Siriayum hastatvats Hay taragirneri kargavijake ev Hay-Arabakan pokhharaberutyunnere 1915-1924 (The status of the Armenian deportees settled in Syria as a result of the Armenian Genocide and the ArmenianArab relations 1915-1924 (Yerevan 2013) 154.

77 Davide Rodogno, Against massacre: humanitarian interventions in the Ottoman empire, 1815-1914 (Princeton 2012). 
drove the anti-Armenian sentiments in mandatory Syria, too. Syrian nationalists referred to their presence as a justification for the French rule:

Armenians say they are foreigners in Syria, therefore they have nothing to do with the local politics and have no duties. [...] They prefer to have Syrian and Lebanese passports in their pockets to have equal rights without fulfilling any citizen duty. Instead, they enjoy Western privileges that prohibit the free future of our country [...].78 (Emphasis mine)

Overall, the 'special' treatment of the Armenian refugees by the French mandatory authorities and the League of Nations further highlighted the 'otherness' of these refugees and widened the gap between the incoming and the hosting communities.

\section{5}

Citizen Strangers: Discourses of the Refugee Political Elites

The Armenian refugees in Syria were anything but a national community in the classical sense in the early 1920s. Being survivors of the Genocide, they formed a veritable conglomeration of all kinds - the (former) rich and the poor, the urban and the rural, the Armenian, Turkish and Kurdish speakers, and were disproportionally composed of women and children. In addition, they were further divided along congregational and political affiliations.

Despite the awareness that the preservation of their plural ethnic and religious identity was endangered, the Armenian refugees initially did not have a clear strategy to establish a distinct community. On the contrary, physical survival was their main concern and repeated calls for adaptation in the Levant were made. ${ }^{79}$

Nevertheless, the strong anti-Armenian reactions became a wake-up call for Armenian refugees, who suddenly realised that Syrian hospitability could not be taken for granted, and therefore new strategies were needed to ensure their peaceful cohabitation. Among the different tactics and strategies used by the Armenian political elite, one can identify the framework suggested by Michel de Certeau in his seminal work The practice of everyday life, whereby the 'weak'

78 Najïb al-Al-qaḍiya al-ärmanïyah fi süriyä; wäjibät al-ärman fi al-baläd' (Armenian issue in Syria; The Duties of the Armenians in Syria), Al Sha'b 5 October 1928.

79 For instance, the letter of the Armenian national delegation of Paris to Sahak Catholicos in February 1922: 'Our people have a great interest in maintaining peaceful and friendly cohabitation with the natives in Syria. At this time of trouble, to be patient and to adapt ourselves is a must [...]', in: B. Eghiayan, Zhamanakakits patmutyun, 265. 
imitates the 'strong' creating a space where it can act within the constraints imposed on them. ${ }^{80}$ It has been observed that whenever nationalism was used by the ruling elites to shape the collective national identity, it was simultaneously borrowed and adapted by the sectarian and ethnic groups to enhance their own distinct identities according to the 'national' model through discrete cultural, linguistic, moral, sociological, even psychological or physical traits. ${ }^{81}$

Likewise, Armenian political parties referred to ethnic nationalism with an attempt to turn the passive and unorganised refugee segments into an organised community by revitalising their patriotic feelings and mobilising them around and against the anti-Armenian rhetoric. ${ }^{82}$ Social life, economic networks and institutions including churches, schools, political parties and charities, gradually emerged. Crucially, however, the Armenian elites failed to overcome the internal diversity and form a united front.

In that regard, leaders of the Ramkavar rightly pointed out that the existing political parties were more of an obstacle than a tool to advance towards national unity. Ironically, they suggested that it was within the refugee camps, despite all of the harsh conditions, that refugees were more prone towards a certain degree of national unity:

Although people live in poverty, they enjoy their daily life, earn money and maintain their national feelings. They like to attend church, send their children to school and remember every day that they are Armenians and they must stay Armenians $[\ldots] .{ }^{83}$ (Emphasis mine)

More critically, the political parties had different and often conflicting views about the future status of the Armenian refugees in Syria. If Hunchak and Ramkavar circles considered the presence of the Armenian refugees in Syria temporary - as 'guests', the ARF, on the contrary, advocated for the permanent resettlement and full integration of Armenians in Syria.

The main bone of contention between the Armenian political parties revolved around the role of Soviet Armenia for Armenian refugees. Ramkavar and Hunchak circles framed their discourse of being a 'guest' by adopting a

\footnotetext{
8o Michel De Certeau, The practice of everyday life (London 1988).

81 Elizabeth Picard, 'Y a-t-il un problème communautaire en Syrie?', Maghreb-Machrek 87 (1980) 7-21.

82 On ethnic nationalism, see Anthony Smith, 'Ethnic myths and ethnic revivals', European Journal of Sociology 25 (1984) 283-305.

83 'Qemberu shurj' (About the camps), Yeprat 30 August 1930.
} 
pro-Soviet Armenia approach and advocated for repatriation. ${ }^{84}$ Hunchak circles believed that Soviet Armenia was the only place where the preservation of an ethnic Armenian identity was both feasible and guaranteed: 'There is just one way to prevent assimilation, to look at Armenia, and if to leave, to leave only for Armenia [...]'85 They also claimed that by establishing contacts with the Soviet motherland, Armenians would prove to the Arabs that their only wish was to form an 'economic community' in Syria without any hidden political goals. ${ }^{86}$ In addition, Hunchak circles suggested that Armenian communities had to keep a distance from the local Syrian politics and concentrate instead on their own community issues. ${ }^{87}$

Ramkavars, however, highlighted the involuntary arrival of the Armenian refugees as well as the temporality of their status and thus their willingness to repatriate:

Armenians did not come willingly to Syria [...]. Nevertheless, we will leave Syria willingly as soon as we have some material and political opportunities to resettle in our motherland [...]. We agree it is a vain attempt to try to resettle us in Syria, as we will never stop considering ourselves guests, no matter how long we live here $[\ldots] .{ }^{88}$ (Emphasis mine)

At the same time, Ramkavars found it necessary to obtain Syrian citizenship, for it would allow the Armenian refugees to upgrade their legal status becoming useful and loyal citizens without losing their Armenianness. ${ }^{89}$

In May 1930, Yeprat published successive articles addressed to the Syrian Arabic press and the wider Syrian public, declaring that: 'we [Armenian

84 Repatriation of the Armenian refugees to the Republic of Armenia and later to the nascent Soviet Armenia was envisaged by the League of Nations and the Soviet authorities. Around 100,000 Armenians were relocated in Soviet Armenia following Stalin's call for repatriation between $1946-1948$.

85 'Artagaghti tarerayin hosanqe' (The continuous flow of the immigration), Suriakan Mam$u l$ i3 June 1926.

86 'Surio hayutian avag partavorutyunneren' (From the most important duties of the SyrianArmenians), Suriakan Mamul 5 August 1923.

87 S. Dodutian, 'Gaghtakane otar erkri mej' (The refugee in a foreign country), Suriyakan Mamul 18 November 1923; 'Qemperu derutyune' (The situation in the camps), Suriyakan Mamul 27 March 1925.

88 'Ankeghts khosqer Damaskosi 'Al-Qapas'in' (Honest Words to the Damascene Al Qabas), Yeprat 14 May 1930.

89 Kiliketsi, 'Inch petk e eni Suriahayutyune? Azgayin pahpanum ev azgayin miutyun' (What should the Syrian Armenians do? National preservation and national unity), Yeprat 3 January 1927 . 
refugees turned citizens] are loyal to our hosts, grateful to the French and friends of the Arabs [...]. ${ }^{90}$ (Emphasis mine)

In contrast, the ARF took a radically different strategy. Allied with the French mandatory authorities, ARF members were hostile towards the communist

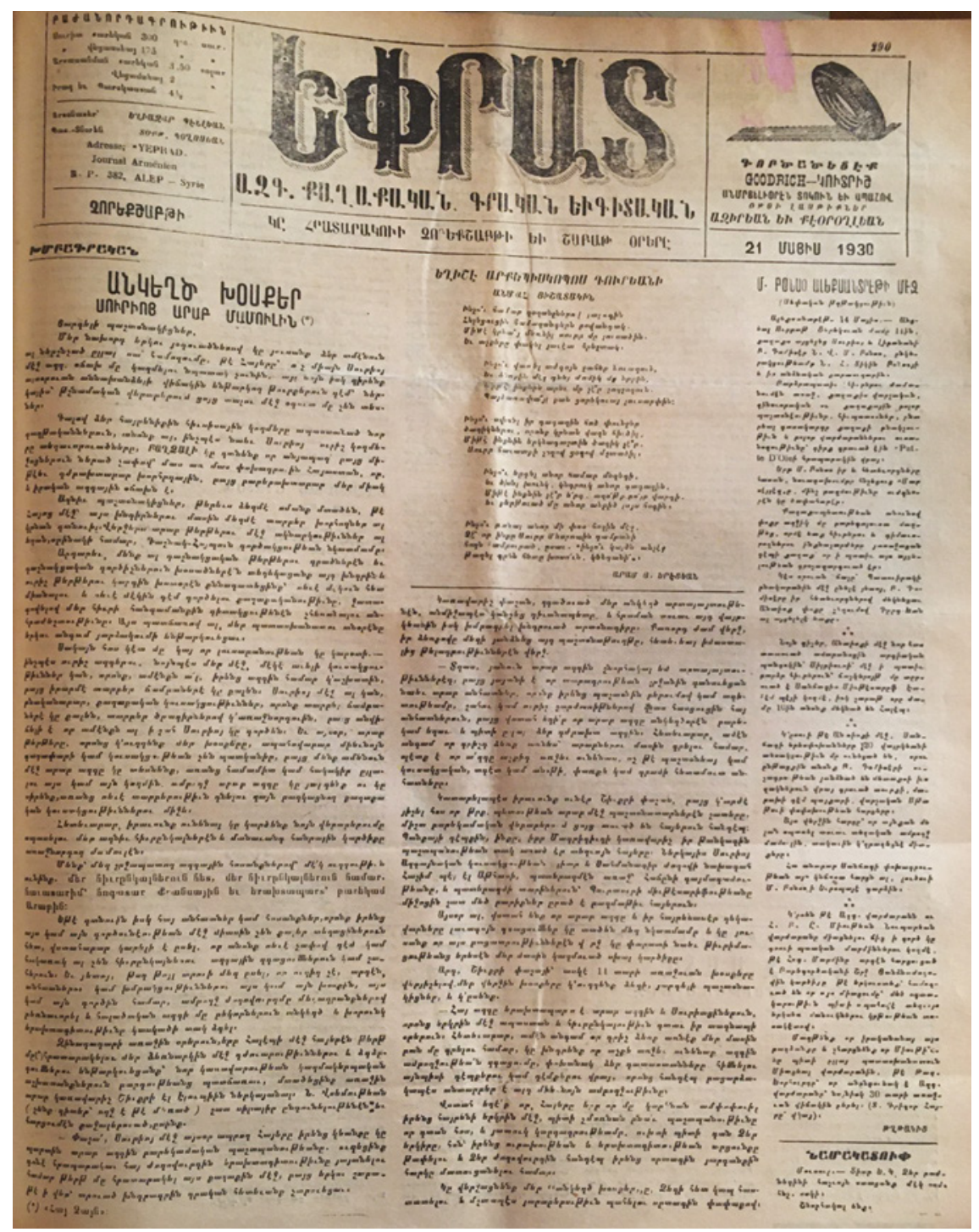

ILlustration 1 'Honest words to the Syrian Arabic press', Yeprat (21 May 1930)

90 'Ankeghts khosqer Damaskosi Al-Qabasin' (Honest words to the Damascene Al-Qabas), Yeprat 14 May 1930; 'Ankeghts khosqer Surio Arab mamulin' (Honest words to the Syrian Arabic press) Yeprat 21 May 1930. 
regime established in Armenia. Consequently, the party advocated for the preservation and empowerment of the Armenian communities in exile by highlighting nationalism and reinforcing ethnic attributes such as their language, traditions and culture. Essentially, it advocated for the isolation of the Armenian refugees, who were encouraged not to take the Syrian citizenship and to form instead a united 'national group' that hopefully would be recognised by the League of Nations. ${ }^{91}$ It is worth recalling, however, that ARF leaders were not always coherent with their 'isolation' strategy as they were equally eager to have representatives in the Syrian parliament. ${ }^{92}$

Writing about the ARF-French collaboration, Topuzyan argued that ARF members were instruments in the hands of French diplomacy that benefited mutually' ${ }^{93}$ For instance, the party always managed to secure a seat in the Syrian Parliament despite their lack of popular support among the Armenian refugees. ${ }^{94}$ Moreover, the ARF favoured French resettlement policies in northern Syria and announced openly: 'Yes, we are resettling in Syria, but not as guests, rather as useful elements that will feed and enrich our hosts [...]'.95 (Emphasis mine)

The strategy of the party to pretend to represent the entire refugee community reinforced the identification of Armenian refugees with the French imperialist agenda, thereby making them a target for the Syrian nationalists. The ARF members, notwithstanding, foresaw the solution to the anti-Armenian rhetoric in asking for the support and the interference of the French mandatory authorities. ${ }^{96}$ Such strategies fatally contributed to deepen the ideological divisions among the Armenian political parties. Ramkavars, in particular, argued that further French involvement would, ultimately, make the Arab uneducated masses even more aggressive towards the Armenians. ${ }^{97}$

Despite the internal divisions and conflicts, the anti-Armenian discourse became an important resource for the Armenian political elites to mobilise and reunite the Armenian refugees in the face of a common external threat. Even though a united Armenian community was not achieved in the interwar years, a distinct community with solid institutions gradually emerged in Syria and Lebanon.

\footnotetext{
91 Margaryan, Hayots tseghaspanutyan hetevanqov, 144.

92 Ibid.

93 Topuzyan, Siriayi ev Libanani haykakan gaghtojakhneri patmutyun, 209.

94 Avetis Injejikian (1923), Narek Abrahamian (1926), Movses Ter-Galustian (1928), Ibid.

95 Aghbalyan Nikol, Syria and Us (Cairo 1932) 12.

96 'Hay-Arab haraberutyunnere Surioi mej; Skhal akhtajanachutyun me' (Syrian-Arab relations in Syria; A wrong diagnoses) Yeprat 30 April 1930. Yeprat's response to Husaber. 


\section{$5 \quad$ Conclusions}

The collapse of the Ottoman Empire and the genocide against the Anatolian Armenians created unprecedented refugee flows to Syria, for which France had obtained an international mandate. Being Christians and non-Arabic speakers, unlike the majority of the Syrian population, the Armenian refugees were categorised as 'outsiders' by the Syrian nationalists. Labels such as 'guests' and 'hosted refugees' were systematically used to underscore the otherness of the Armenians, regardless of their legal status.

Crucially, the anti-Armenian discourse that emerged under the French tutelage around the questions of citizenship, voting rights, inclusion and exclusion, played a significant role in consolidating the definition of the Syrian national identity closely identified with Islam and Arabness. Furthermore, the policies implemented by both the League of Nations and the French mandatory authorities made the gap between the hosting and the incoming communities even bigger.

In their turn, the Armenian political elites in Syria took on the anti-Armenian discourse to mobilise their compatriots against and/or around it. Ultimately, the interplay of these discourses throughout the mandate years created mutually excluding national identities.

\section{Acknowledgement}

I would like to express my thanks to my research supervisor Professor Jordi Gorgas Tejel and my colleague Ramazan Hakki Öztan for reading the earlier versions of this article. This project has received funding from the European Research Council (ERC) under the European Union's Horizon 2020 research and innovation programme (grant agreement 725269 ) as well as from Gerda Henkel Stiftung. 